\title{
Meloxicam administration either prior to or after parturition: Effects on behavior, health, and production in dairy cows
}

\author{
T. H. Swartz, ${ }^{*}$ H. H. Schramm,† J. M. Bewley, $\ddagger$ C. M. Wood,§ K. E. Leslie,\# and C. S. Petersson-Wolfe ${ }^{* 1}$ \\ *Department of Dairy Science, Virginia Tech, Blacksburg 24061 \\ †VA-MD College of Veterinary Medicine, Blacksburg, VA 24061 \\ ‡CowFocused Housing, Bardstown, KY 40004 \\ $\S D e p a r t m e n t$ of Animal and Poultry Sciences, Virginia Tech, Blacksburg 24061 \\ \#Department of Population Medicine, University of Guelph, Guelph, ON, Canada, N1G 2W1
}

\section{ABSTRACT}

Parturition is often a stressful period, when the incidence of disease is high after calving, which has been associated with an uncontrolled inflammatory response. Therefore, the objective of this study was to test the effect of the administration of a nonsteroidal anti-inflammatory drug (meloxicam) on the behavior, health, and production of peripartum cows. Meloxicam was dosed at $1 \mathrm{mg} / \mathrm{kg}$ of body weight, and an empty gel capsule served as a placebo. Both were administered orally with a balling gun. Dairy cows and heifers were randomly assigned to 1 of 3 treatment groups: (1) meloxicam administration before calving, with a placebo administered after calving (MEL-PRE, $n$ $=60)$, (2) placebo administered before calving, and meloxicam administered after calving (MEL-POST, n $=69$ ), and (3) a placebo administered before calving and after calving $(\mathrm{CTL}, \mathrm{n}=65)$. To identify imminent calving events, a vaginal thermometer was inserted approximately 2 wk before the expected calving date and a drop in temperature was used to identify cows close to calving. Calving events were monitored via video cameras, and the amount of time that elapsed between the appearance of the amniotic sac at the vulva until delivery of the calf was used to determine calving difficulty score. Eutocic calving events were defined as cows that calved in $\leq 70 \mathrm{~min}$, and dystocia was defined as cows that took longer than $70 \mathrm{~min}$ to calve. Milk yield and components were measured for the first 15 wk of lactation and accelerometers were used to record activity and lying behaviors. The effects of treatment, breed, parity, calving difficulty, and, when applicable, a repeated measure, along with interaction terms, were analyzed in mixed models. Regardless of the time of administration, dystocic cattle that received meloxicam

Received February 27, 2018.

Accepted June 29, 2018.

${ }^{1}$ Corresponding author: milk@vt.edu were less active than dystocic CTL. Dystocic animals displayed more lying bouts on the day of calving and then displayed fewer lying bouts and were less active during the days following calving. No effect of treatment was noted on any health outcomes. Eutocic MELPRE animals produced $6.8 \mathrm{~kg} / \mathrm{d}$ more milk than eutocic CTL. Regardless of calving difficulty, MEL-PRE animals produced more milk fat, protein, and lactose $(\mathrm{kg} / \mathrm{d})$ than CTL. In conclusion, meloxicam administration before calving appears promising in increasing milk yield in eutocic cows.

Key words: periparturient dairy cow, nonsteroidal anti-inflammatory drug, meloxicam, behavior

\section{INTRODUCTION}

Parturition is a risky period when the incidence of disease, injury, and mortality are high around the time of calving. This increase in disease incidence has been associated with an uncontrolled inflammatory response (Sordillo and Raphael, 2013). After calving, inflammation has been documented in both healthy and diseased cattle (Humblet et al., 2006; Bionaz et al., 2007; Huzzey et al., 2009; Graugnard et al., 2012; Mullins et al., 2012; $\mathrm{Qu}$ et al., 2014). These data suggest that cattle experience at least some degree of inflammation due to tissue damage associated with parturition, as well as the immense metabolic demand associated with the onset of lactation (Bradford et al., 2015).

Dystocia, defined as delayed or difficult calving, is associated with a heightened inflammatory response. The odds of an elevated concentration of haptoglobin, an inflammatory marker, were 2.5 times greater in multiparous animals with an assisted calving compared with those who did not require assistance (Pohl et al., 2015). Furthermore, dystocia increases the odds of retained placenta, displaced abomasum, and metritis (Correa et al., 1993), resulting in a decrease in milk, fat, and protein yields, as well as an increase in days open, number of services, and mortality rates (De- 
matawewa and Berger, 1997). In particular, dystocia reduced peak milk yield by approximately $2 \mathrm{~kg} / \mathrm{d}$ in multiparous cows (Atashi et al., 2012). The incidence of dystocia can vary from herd to herd; however, in North America, literature suggests 10 to $40 \%$ of cows will experience a difficult birth (Meyer et al., 2001; Lombard et al., 2007; USDA-APHIS, 2010). The implications of this heightened inflammatory state are not completely understood; however, inflammatory markers such as haptoglobin are markedly greater preceding clinical disease onset in cattle (Qu et al., 2014). Aside from milk fever, clinical disease incidences during the periparturient period have remained unchanged in the dairy industry over the past 20 to $30 \mathrm{yr}$ (Goff, 2006; USDA-APHIS, 2008; Bradford et al., 2015).

One potential solution to this problem is the administration of a nonsteroidal anti-inflammatory drug (NSAID) to reduce inflammation in the periparturient dairy cow. In the United States, flunixin meglumine is the only FDA-approved NSAID for use in cattle (Coetzee, 2013). The administration of flunixin meglumine around the time of calving has been unsuccessful in reducing disease incidence (Shwartz et al., 2009; Newby et al., 2017). In fact, flunixin meglumine administration increased the risk for retained placenta, elevated rectal temperature, decreased milk yield, and a higher incidence of metritis when compared with controls (Newby et al., 2017). When flunixin meglumine was administered before calving, treatment increased the number of stillborn calves by 5 fold when compared with controls (Newby et al., 2017).

Another NSAID, meloxicam, has been approved for use in cattle in many European countries as well as Canada. Past research has examined the effect of meloxicam administration in periparturient dairy cows with variable results (Newby et al., 2013; Mainau et al., 2014; Carpenter et al., 2016). Mainau et al. (2014) found that postcalving meloxicam administration to eutocic primiparous animals resulted in an increase in activity for the first $2 \mathrm{~d}$ postcalving when compared with eutocic primiparous controls. Newby et al. (2013) found that meloxicam-treated cows following a dystocic calving visited the feed bunk more often and spent more time feeding than control dystocic cows. Lastly, postcalving meloxicam administration increased milk yield (MY) by $4 \mathrm{~kg} / \mathrm{d}$ for a 305-d lactation when compared with controls, with the majority of this effect occurring during peak lactation (Carpenter et al., 2016). However, these studies administered meloxicam after calving only. If the processes of parturition are the underpinning of the heightened inflammatory state, administration of an NSAID directly before calving to alleviate inflammation may have merit.
Because cattle are pain tolerant, identification of discomfort can be a challenging task (Weary et al., 2006). More recently, the use of technologies identifying changes in behavior have proven capable of identifying discomfort in cattle (Weary et al., 2009). For instance, cows that went on to have a dystocic calving exhibited more standing bouts (Proudfoot et al., 2009) and lying bouts (Yeiser, 2011) during the final day before calving or on the day of calving, as well as a reduction in activity after calving when compared with cows that had a eutocic calving (Barragan et al., 2017b). Therefore, the use of these behaviors may be of value in detecting treatment effect from NSAID therapy in peripartum cows.

Therefore, the objective of our study was to compare the effect of meloxicam administration before or after calving on behavior, health, and production measures in dairy cows. We hypothesized that the administration of meloxicam before calving would increase activity measures and MY more so than postcalving administration, and that both treatment groups would be more active on the days following calving, display fewer lying bouts on the day of calving, and produce more milk than controls. Moreover, because dystocia exacerbates the heightened inflammatory state that already occurs around calving, we hypothesized that NSAID-treated dystocic cows would be more responsive to treatment than NSAID-treated eutocic cows. We also anticipated meloxicam treatment to result in a greater MY response in dystocic animals than eutocic animals when compared with their respective controls.

\section{MATERIALS AND METHODS}

This study was conducted at the Virginia Tech Dairy Research Complex in Blacksburg, Virginia, with enrollment occurring from August 2016 through August 2017. All experimental procedures were approved by the Virginia Tech Institutional Animal Care and Use Committee (14-265).

\section{Housing and Diets}

Approximately $3 \mathrm{wk}$ before the expected calving date, pregnant dry cows and heifers $(\mathrm{n}=237)$ were moved to group housing in a compost-bedded pack barn with access to a close-up dry cow TMR. The close-up dry cow TMR consisted of grass hay, corn silage, and a grain mix. Cows calved in group housing and remained in this pen until after calving. Group size was dynamic; however, a minimum of $9.3 \mathrm{~m}^{2}$ (100 square feet) per cow was maintained. Following calving, cows were moved into an adjacent compost-bedded pack pen where they 
remained for the first 7 DIM. While housed in this compost-bedded pack pen, group size was dynamic; however, a minimum of $9.3 \mathrm{~m}^{2}$ (100 square feet) per cow was maintained. After the first week of lactation, cows were moved into a deep sand-bedded freestall barn, where they remained for the rest of the trial. Stocking density of the freestall barn was maintained between 100 to $110 \%$ (cows per stall multiplied by 100). Lactating cows were fed a TMR that consisted of corn silage, triticale-mixed clover silage, alfalfa hay, and a grain mix. At $24 \mathrm{~kg}$ of $\mathrm{DM}$ (52 lb of DM), the ration was balanced for $39 \mathrm{~kg} / \mathrm{d}(85 \mathrm{lb} / \mathrm{d})$ milk production that met or exceeded NRC (2001) requirements. Cows were fed once daily and feed was pushed up 4 times per day.

\section{Design and Treatments}

Just before arrival in the close-up dry cow pen, animals were weighed using an automated scale (AfiWeigh, Afimilk Ltd., Kibbutz Afikim, Israel), and this weight was used to determine the appropriate meloxicam dosage for administration around calving $[1 \mathrm{mg} / \mathrm{kg}$ of $\mathrm{BW}$, administered by mouth; Meloxicam tablets, USP (15 mg), Cipla Ltd., Kurkumbh, India]. Meloxicam tablets were placed into gel capsules and an empty gel capsule was used as a placebo. Both were administered using a balling gun. To administer boluses, cows were restrained using a headlock at the feed bunk. Using the random function in Microsoft Excel (Microsoft Corp., Redmond, WA), cows and heifers were randomly assigned to 1 of 3 treatment groups: (1) meloxicam administration no more than $48 \mathrm{~h}$ before calving and no less than $6 \mathrm{~h}$ before calving, and a placebo administered within $12 \mathrm{~h}$ postcalving (MEL-PRE); (2) placebo administration no more than $48 \mathrm{~h}$ before calving and no less than $6 \mathrm{~h}$ before calving, and meloxicam administered within 12 $\mathrm{h}$ postcalving (MEL-POST); and (3) placebo administration no more than $48 \mathrm{~h}$ before calving and no less than $6 \mathrm{~h}$ before calving, and a placebo administered within $12 \mathrm{~h}$ postcalving (CTL). The precalving treatment window was based upon a previous pharmacokinetic study (Malreddy et al., 2013), where meloxicam concentration peaked approximately $11 \mathrm{~h}$ after oral administration in mid-lactation cows. However, more recently, a pharmacokinetic study (Gorden et al., 2018) demonstrated that meloxicam concentration peaked at $18 \mathrm{~h}$ after oral administration in postpartum cows and had a greater bioavailability in postpartum cows when compared with mid-lactation cows.

Pregnant dry cows and heifers had a vaginal thermometer (Vel'Phone, Medria, Châteaubourg, France) inserted approximately $14 \mathrm{~d}$ before their expected calving date. This device was used to detect the drop in vaginal temperature that occurs within $48 \mathrm{~h}$ before calving (Burfeind et al., 2011; Saint-Dizier and Chastant-Maillard, 2015; Ouellet et al., 2016). When vaginal temperature declined approximately $0.6^{\circ} \mathrm{C}$ or more (to about $38.0^{\circ} \mathrm{C}$ ), the treatment regimen was initiated. Because vaginal temperature has a moderate sensitivity for identifying imminent calving events, some cows did not receive treatment before calving or the treatment did not occur in the precalving treatment window and were excluded from analysis $(\mathrm{n}=33)$. Furthermore, cows that calved with twins $(\mathrm{n}=9)$ or calved via cesarean section $(\mathrm{n}=1)$ were also excluded. Therefore, the final sample size $(\mathrm{n}=194 ; 87$ multiparous Holstein, 48 primiparous Holstein, 41 multiparous Jersey, and 18 primiparous Jersey; calving distribution by season: winter, $\mathrm{n}=49$; spring, $\mathrm{n}=54$; summer, $\mathrm{n}=46$; and autumn, $\mathrm{n}=45$ ) included only cows that calved vaginally with single births (Table 1; MEL-PRE, $\mathrm{n}=60$; MEL-POST, $\mathrm{n}=69$; CTL, $\mathrm{n}=65$ ).

\section{Dystocia Scoring}

Pregnant dry cows and heifers were continuously monitored $24 \mathrm{~h} / \mathrm{d}$ using 3 video cameras (Axis P1353E, Axis Communications AB, Lund, Sweden). These cameras were equipped with Lightfinder technology and required only minimal lighting during night hours. The camera feeds were transmitted via an Ethernet cord to a computer and were stored in 3-h segments using video recording software (Media Recorder, Noldus Information Technology Inc., Leesburg, VA). Dystocia is typically quantified in a scoring system using the amount of assistance as the determining factor for the degree of difficulty; however, these scoring systems can be subjective. More recently, a study examined the amount of time between the presence of the amniotic sac at the vulva and the expulsion of the calf (stage 2 of labor) between eutocic and dystocic calvings, and concluded that a calving event $>70$ min should be assisted (Schuenemann et al., 2011). Therefore, in the present study, dystocia was defined when stage 2 of labor was $>70 \mathrm{~min}$ and eutocia was defined as $\leq 70$ min. Apart from 2 cows, eutocic calving events were not provided with assistance. In those 2 calving events, the farm managers deemed that the calf needed to be extracted due to an emergency, such as malpresentation of the fetus. Statistical analyses were conducted with and without these 2 cows and the results from both analyses were the same. Therefore, these 2 cows remained in the study, and were included in the eutocic calving events, as both calving events were less than 70 min in length. The determination of which animals required assistance during calving was left to the discretion of the farm managers and staff and was performed 
as part of routine farm management. Farm managers and staff were masked to treatments during calving to prevent bias toward assisting calvings in one treatment group over another. Assistance intensity was also recorded using a 1 to 3 scale, where $1=$ no assistance, 2 = easy pull requiring only 1 person with no mechanical assistance, and $3=$ difficult pull requiring 2 or more people with or without mechanical assistance (Table 1).

\section{Behavior}

Upon entry into the close-up dry cow pen, animals were fitted with an accelerometer (AfiTag II, AfiMilk Ltd.) that measured activity, lying time, and lying bouts. These behaviors were collected wirelessly every $30 \mathrm{~min}$ and transmitted to a computer (AfiAct II, Afimilk Ltd.). Data were summarized into activity (steps/d), lying time (min/d), and lying bouts (no./d). Lying bout duration was calculated by dividing the lying time by the number of lying bouts on that day. Data recording from the accelerometer began $14 \mathrm{~d}$ before the expected calving date and concluded at 7 DIM. Data from $\mathrm{d}-3$, the day before treatment regimen, was used as a covariate to account for individual differences in behaviors. Some cows did not have $\mathrm{d}-3$ data due to either missing data, accelerometer malfunction, or technical problems with the wireless data collection system. Therefore, the final sample size for the behavioral data included 165 cows (MEL-PRE, $\mathrm{n}=53$; MEL-POST, $\mathrm{n}=59$; CTL $\mathrm{n}=53$ ). Because cows were eligible for treatment regimen starting $2 \mathrm{~d}$ before calving $(\mathrm{d}-2)$, data from $\mathrm{d}-2$ through $\mathrm{d} 7$ (with $\mathrm{d} 0$ designated as the day of calving) were analyzed for the effect of treatment.

\section{Health}

Rectal temperatures for the first 7 DIM were taken at approximately $0900 \mathrm{~h}$ using a digital rectal thermometer (SharpTemp V, Cotran Corp., Portsmouth, RI). Clinical disease events were diagnosed by 2 university veterinarians, who were masked to treatments, for the first 30 DIM. Both of these veterinarians have more than $10 \mathrm{yr}$ of experience in the veterinary field. Cattle were monitored daily for disease events, and these data were recorded in farm management software (PC Dart,

Table 1. Descriptive statistics $( \pm \mathrm{SD})$ for 194 cows receiving meloxicam before calving (MEL-PRE, $\mathrm{n}=60$ ), after calving (MEL-POST, $\mathrm{n}=69$ ), or a negative control $(\mathrm{CTL}, \mathrm{n}=65)$

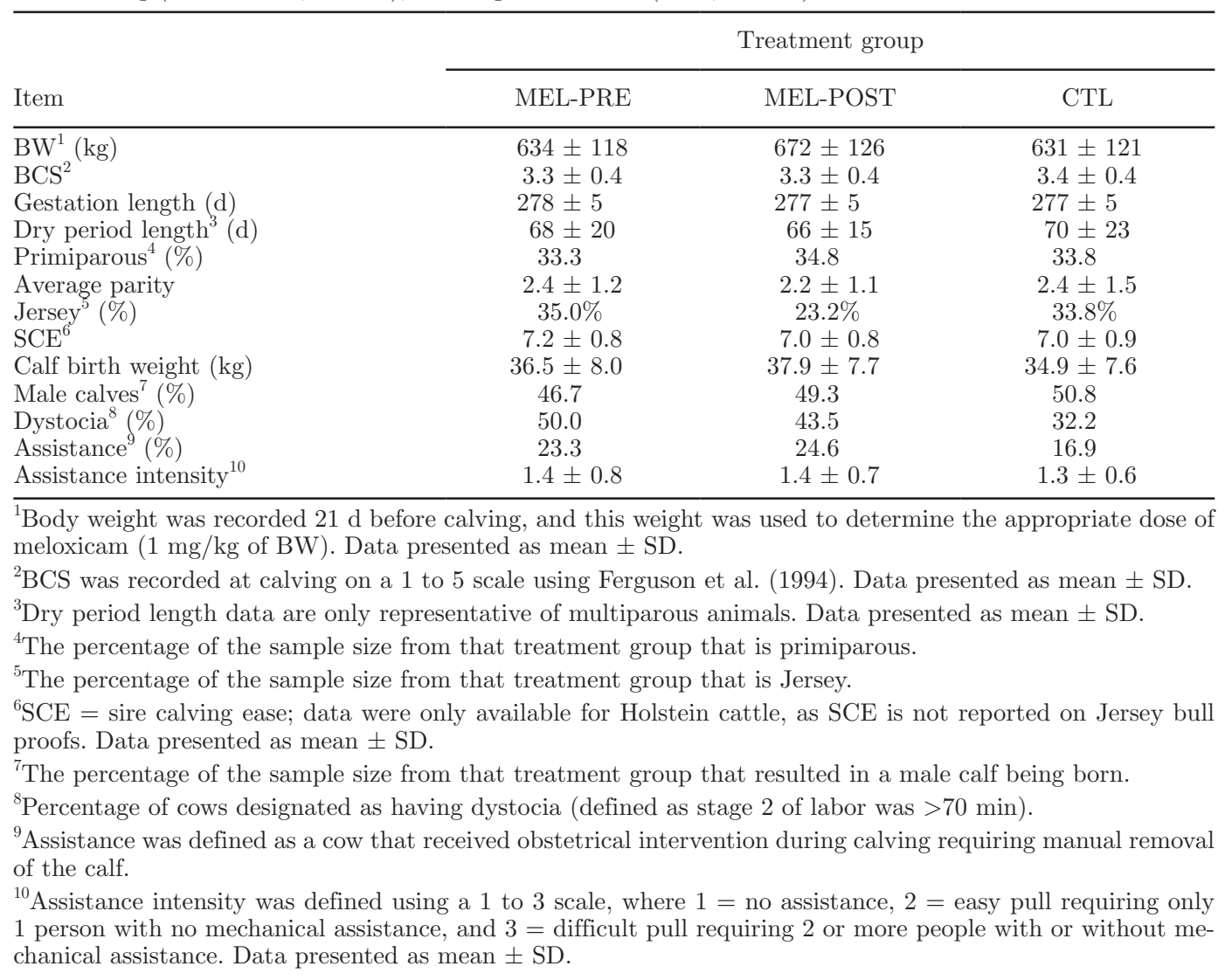


Dairy Records Management Systems, Raleigh, NC). These diseases included retained fetal membranes, milk fever, clinical mastitis, clinical ketosis, metritis, and left-displaced abomasum. All clinical disease events were defined following Kelton et al. (1998). A cow was considered to have a retained placenta when the fetal membranes were visible outside the vulva for more than $24 \mathrm{~h}$ after calving. A cow was considered to have milk fever if she displayed clinical signs consistent with stages 1,2, and 3 of the disease defined in Kelton et al. (1998) within the first $72 \mathrm{~h}$ of calving. Clinical mastitis was defined as abnormal milk (e.g., clots, flakes, watery) from one or more quarters. Clinical ketosis was defined as a cow with a depressed appetite and elevated concentrations of ketone bodies in urine, milk, or blood tests. Metritis was defined as a cow with a fetid smelling, watery vaginal discharge with systemic signs of illness (with or without fever). A cow was considered to have a left-displaced abomasum when she had an audible, high-pitched tympanic resonance (ping) produced by percussion of the left abdominal wall between the 9th and 12th ribs accompanied with a depression in appetite. Stillbirth was defined as a calf that was born dead. One calf was born deformed and required euthanasia; therefore, this calf was excluded from the stillbirth analysis. A single blood sample was taken $3 \mathrm{~d}$ after calving for BHB testing using a previously validated hand-held meter (Bach et al., 2016; Nova Vet Meter, Nova Biomedical, Waltham, MA). Lastly, BCS was recorded on the day of calving, using a 1 to 5 scale, with 1 being emaciated and 5 being obese (Ferguson et al., 1994).

\section{Milk Yield and Milk Components}

Cows were milked twice daily in a double 12 parallel parlor. Milk was weighed through an automated milk meter and milk components (fat, protein, and lactose) were analyzed via near-infrared spectroscopy (NIR) at each milking for the first $15 \mathrm{wk}$ of lactation (AfiMilk MPC Milk Meter and AfiLab Milk Analyzer, Afimilk Ltd.). This NIR system has been previously validated (Kaniyamattam and De Vries, 2014). Milk was discarded for the first 7 DIM, after it passed through the meter and the NIR system, to ensure no residues from meloxicam treatment would enter the food supply.

\section{Statistical Analysis}

Mixed models (PROC GLIMMIX, SAS ver. 9.4, SAS Institute Inc., Cary, NC) were used to analyze the data. For the behavioral response variables of lying time, steps, lying bouts, and lying bout duration, fixed effects included treatment (MEL-PRE, MEL-POST, or
CTL), breed (Holstein or Jersey), parity (primiparous or multiparous), and calving difficulty score (eutocia or dystocia). A repeated measure (day) was included and cow was modeled as a random effect. Data from $\mathrm{d}-3$ (the day before treatment regimen) for the variable of interest was used as a covariate to account for individual differences in those behaviors.

For the response variables of daily milk yield, milk protein, milk fat, and milk lactose, fixed effects included treatment, breed, parity, and calving difficulty score. A repeated measure (week of lactation) was included and cow was modeled as a random effect. The PTA for the variable of interest (PTA milk, PTA fat, or PTA protein) was included as a covariate in the model to account for genetic differences contributing to variation. Because a genetic parameter for lactose yield does not exist, the PTA for milk yield was used for the lactose model instead. Body condition score recorded on the day of calving was tested as a covariate in milk responses. Additionally, for milk yield and all milk components models, interaction terms of treatment with their respective covariates (PTA milk, PTA fat, PTA protein, or BCS) were tested.

For the response variable of rectal temperature, fixed effects included treatment, breed, parity, and calving difficulty score with a repeated measure of day. When BHB was evaluated, fixed effects included treatment, breed, parity, and calving difficulty score. Body condition score was included in this model as a covariate.

For the models described above, all 2- and 3-way interaction terms of the fixed effects were introduced into the model. If the model included a repeated measure, repeated measures over time within cow were modeled using the autoregressive error structure and the Kenward-Roger procedure was used for degrees of freedom approximation (Kenward and Roger, 1997). Backward elimination was used to eliminate nonsignificant terms from highest to least significant until all variables were significant $(P \leq 0.05)$; however, the main effect of treatment was forced into the model regardless of significance. Main effects were retained in the model if $P \leq 0.05$ or if the main effect was involved in a significant interaction term. Two-way interaction terms were retained if $P \leq 0.05$ or if the interaction term was involved in a significant 3-way interaction term. For interaction terms involving treatment, simple effects tests were investigated using the SLICEDIFF option and Tukey adjusted $P$-values were declared significant at $P \leq 0.05$.

Calving length in minutes was analyzed as a continuous response variable to determine if precalving meloxicam administration affected the length of stage 2 of labor (time elapsed from the presence of amniotic sac until delivery of calf). This model included fixed effects 
of treatment (MEL-PRE, MEL-POST, CTL), breed (Holstein or Jersey), parity (primiparous or multiparous), and calving assistance (assisted or not assisted). For all models, the residuals were checked for normality and outliers. Calving length was not normally distributed, and therefore a logarithmic transformation was used. All other data were normally distributed, and all assumptions of the model were met. Significance was declared at $P \leq 0.05$.

For categorical health measures (clinical ketosis, milk fever, retained placenta, displaced abomasum, metritis, clinical mastitis, the number of cows with multiple disease events, dystocia, and stillbirth), Fisher's exact test was used to detect differences in the frequency of these events between treatments (PROC FREQ, SAS ver. 9.4, SAS Institute Inc.). Significance was declared at $P \leq 0.05$.

\section{RESULTS}

\section{Behavioral Data}

Significant main effects and interactions for activity, lying bouts, lying time, and lying bout duration are provided in Table 2. Covariates used in each individual model (either activity, lying time, lying bouts, or lying bout duration data from $\mathrm{d}-3$ ) were significant (all $P$ $<0.01)$.

Lying Time. No effect of treatment or calving difficulty score was identified for lying time. Treatment least squares means \pm standard error for lying time were $578 \pm 10,586 \pm 10$, and $560 \pm 10 \mathrm{~min} / \mathrm{d}$ for MELPRE, MEL-POST, and CTL, respectively.

Activity. For activity, the treatment by calving difficulty score interaction term was significant $\left(F_{2,275}=\right.$ $3.72, P=0.03)$, and this term was sliced by calving difficulty score to determine the simple effects of treatment within calving difficulty (Figure 1). No treatment effect was found in the eutocic animals. However, dystocic MEL-PRE animals were less active than dystocic CTL $\left(t_{268}=2.95, P<0.01\right)$. Moreover, dystocic MEL-POST animals were also less active than dystocic CTL $\left(t_{269}\right.$ $=-3.39, P<0.01)$. No difference was noted between dystocic MEL-PRE and dystocic MEL-POST animals.

The 3-way interaction of treatment, breed, and day was significant (Table $3 ; F_{18,1341}=1.62, P=0.05$ ). This 3 -way interaction term was sliced by the 2 -way interaction term, breed by day, to determine the simple effect

Table 2. Probability level for main effects and interaction terms for lying time (min/d), activity (steps/d), lying bouts (no./d), and lying bout duration ( $\mathrm{min} /$ bout) measured $2 \mathrm{~d}$ before calving until $7 \mathrm{~d}$ after calving with cows receiving meloxicam before calving $($ MEL-PRE, $\mathrm{n}=53$ ), after calving (MEL-POST, $\mathrm{n}=59$ ), or a negative control $(\mathrm{CTL}, \mathrm{n}=53$ )

\begin{tabular}{|c|c|c|c|c|}
\hline Fixed effect & Lying time & Activity & Lying bouts & Lying bout duration \\
\hline Covariate lying bouts $(\mathrm{d}-3)^{1}$ & NA & $<0.01$ & NA & $\mathrm{NA}$ \\
\hline Covariate lying time $(\mathrm{d}-3)^{1}$ & NA & NA & $<0.01$ & NA \\
\hline Treatment & 0.12 & $<0.01$ & 0.60 & 0.84 \\
\hline Breed & $<0.01$ & $<0.01$ & 0.02 & 0.01 \\
\hline Parity & $<0.01$ & $<0.01$ & 0.24 & $<0.01$ \\
\hline Calving difficulty $\times$ breed & - & 0.60 & - & - \\
\hline Treatment $\times$ breed & - & $<0.01$ & - & - \\
\hline Treatment $\times$ parity & - & - & 0.93 & - \\
\hline Treatment $\times$ calving difficulty & - & 0.03 & - & - \\
\hline Day & $<0.01$ & $<0.01$ & $<0.01$ & $<0.01$ \\
\hline Treatment $\times$ day & - & 0.53 & $<0.01$ & - \\
\hline Breed $\times$ day & 0.02 & $<0.01$ & - & - \\
\hline Treatment $\times$ parity $\times$ day & - & - & $<0.01$ & - \\
\hline
\end{tabular}

${ }^{1}$ Behavioral data from $\mathrm{d}-3$, the day before treatment regimen began, was used as a covariate to account for individual differences in behavior. Activity (steps) from $\mathrm{d}-3$ was only included in the activity model, just as lying bouts from $\mathrm{d}-3$ was only included in the lying bouts model, lying time from $\mathrm{d}-3$ was only included in the lying time model, and lying bout duration from $\mathrm{d}-3$ was only included in the lying bout duration model.

${ }^{2} \mathrm{NA}=$ not applicable.

${ }^{3}$ Dashed line represents a term that was not significant for that specific model $(P>0.05)$ and therefore was removed during backward elimination. Terms that were not significant for any of the behavioral models were removed during backward elimination and are not included in the table. 
of treatment within breed and day. No differences were found between treatment groups within the Holstein breed; however, a treatment effect was noted in the Jersey breed. Jersey animals that received meloxicam before calving were significantly less active on $\mathrm{d}-1$ $\left(t_{807}=2.58, P=0.03\right), 1\left(t_{789}=3.22, P<0.01\right)$, and $2\left(t_{790}=2.62, P=0.02\right)$ when compared with Jersey CTL. Furthermore, Jersey MEL-PRE were less active than Jersey MEL-POST on d $2\left(t_{881}=2.55, P=0.03\right)$. Jersey cattle that received meloxicam after calving were less active than Jersey CTL on d $6\left(t_{804}=-2.63\right.$, $P=0.02)$ and $7\left(t_{790}=-3.54, P<0.01\right)$.

The 3-way interaction term of calving difficulty score, breed, and day was significant (Table $4 ; F_{9,1302}$ $=1.88, P=0.05)$. This interaction term was sliced by the 2-way interaction term, breed by day, to determine the simple effects of calving difficulty within breed and day. Dystocic Holstein animals demonstrated a reduction in activity on $\mathrm{d} 1\left(F_{1,829}=8.88, P<0.01\right), 4$ $\left(F_{1,801}=3.84, P=0.05\right)$, and $5\left(F_{1,826}=4.11, P=\right.$ 0.04) when compared with eutocic Holstein. Dystocic Holstein animals tended to be less active on d $0\left(F_{1,808}\right.$ $=3.55, P=0.06)$ and $2\left(F_{1,816}=3.10, P=0.08\right)$ than eutocic Holstein animals. The effect of dystocia on Jersey cattle was a bit less pronounced, as dystocic Jersey animals displayed a reduction in activity only on

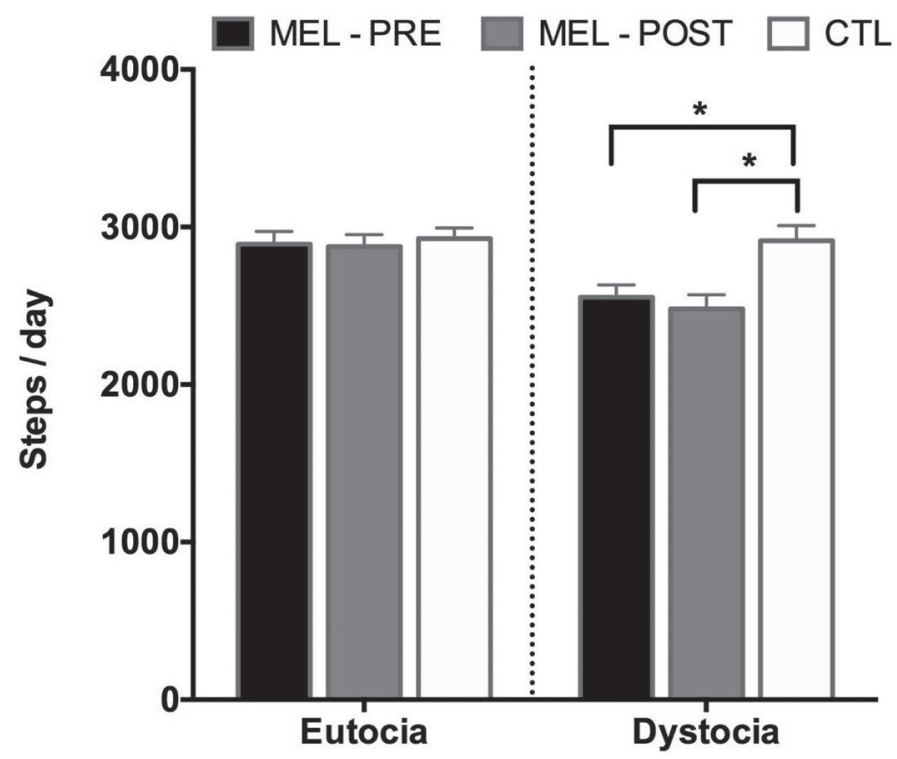

Figure 1. Average daily activity (steps/d; LSM \pm SE) of the treatment by calving difficulty score interaction term, comparisons made within calving difficulty. Data recorded for $10 \mathrm{~d}$, beginning on $\mathrm{d}-2$ and concluding on $\mathrm{d} 7$ (d 0 was designated as the day of calving). Treatments included administration of meloxicam $(1 \mathrm{mg} / \mathrm{kg}$ of BW by mouth) before calving (MEL-PRE), after calving (MEL-POST), and a negative control (CTL). Sample sizes for eutocia were MEL-PRE, n $=26$, MEL-POST, $\mathrm{n}=33$, and CTL, $\mathrm{n}=37$; and for dystocia were MEL-PRE, $\mathrm{n}=27$, MEL-POST, $\mathrm{n}=26$, and CTL, $\mathrm{n}=16$. Differences between treatment groups are denoted as ${ }^{*} P \leq 0.05$.

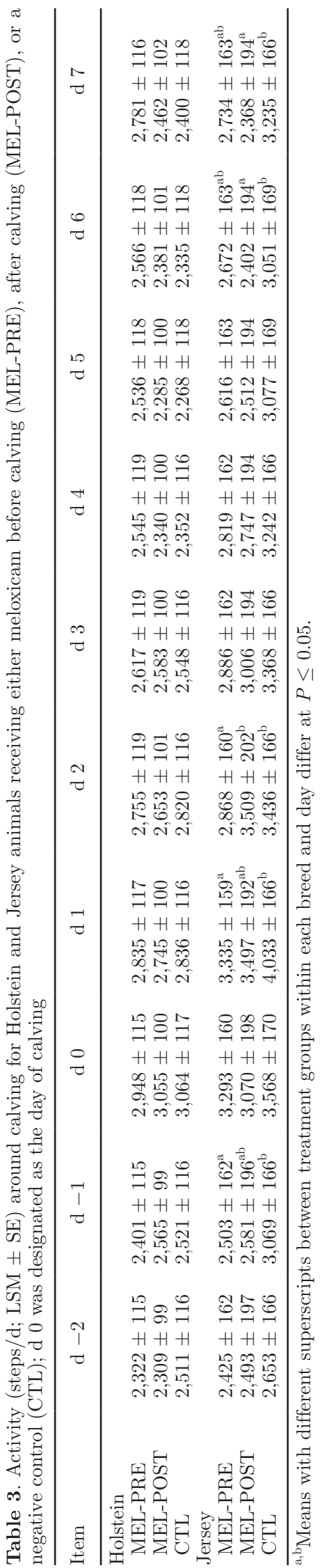

Journal of Dairy Science Vol. 101 No. 11, 2018 


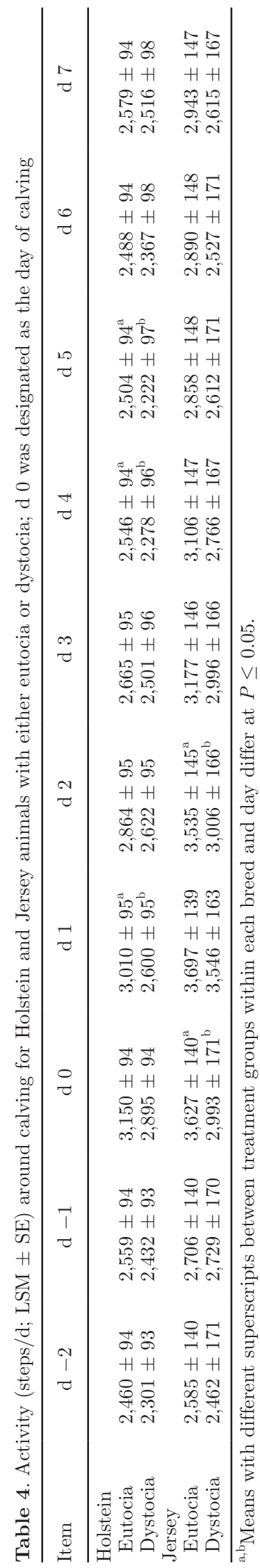

d $0\left(F_{1,863}=8.03, P<0.01\right)$ and $2\left(F_{1,836}=5.78, P=\right.$ $0.02)$ when compared with eutocic Jersey.

Lying Bouts. For lying bouts, the 3-way interaction term of treatment, parity, and day was significant (Figure $2 ; F_{18,1357}=2.01, P<0.01$ ). Simple effects of the interaction term were investigated to determine the effect of treatment on lying bouts within each day. No effect of treatment was found between treatment groups of multiparous animals. However, primiparous MEL-PRE animals had more lying bouts on d 0 than primiparous CTL $\left(t_{1102}=-3.41, P<0.01\right)$ and primiparous MEL-POST $\left(t_{1072}=-4.80, P<0.01\right)$. Moreover, on d 0, primiparous MEL-PRE animals had a similar number of lying bouts as multiparous cows. Furthermore, primiparous CTL had fewer lying bouts on the day of calving than that of all treatment groups of multiparous animals (all comparisons $P \leq 0.04$ ). Similarly, primiparous MEL-POST animals had fewer lying bouts on the day of calving when compared with all treatment groups of multiparous animals (all comparisons $P<0.01)$. A parity effect was identified on the day before calving, as primiparous MEL-POST animals showed more lying bouts than multiparous MEL-POST $\left(t_{1060}=-2.98, P=0.03\right)$.

The calving difficulty score by day interaction term was significant (Figure 3a; $F_{9,1304}=8.72, P<0.01$ ). Dystocic animals had a higher frequency of lying events on d 0 than eutocic animals $\left(F_{1,1079}=41.68, P<0.01\right)$. After calving, dystocic animals had a reduction in lying bouts on $\mathrm{d} 2\left(F_{1,1054}=5.12, P=0.02\right)$ when compared with eutocic animals. Dystocic animals tended to have fewer lying bouts on d $1\left(F_{1,1057}=3.12, P=0.08\right), 3$ $\left(F_{1,1054}=2.99, P=0.08\right)$, and $4\left(F_{1,1042}=3.45, P=\right.$ $0.06)$ than eutocic animals.

Lying Bout Duration. For lying bout duration, no effect of treatment was identified. Treatment least squares means \pm standard error were $51 \pm 1,52 \pm$ 1 , and $51 \pm 1 \mathrm{~min} /$ bout for MEL-PRE, MEL-POST, and CTL, respectively. The calving difficulty score by day interaction term was significant $\left(F_{9,1342}=1.97, P\right.$ $=0.04$ ), and simple effects of calving difficulty were investigated within day (Figure 3b). Dystocic animals spent more time lying per bout on d $1\left(F_{1,1075}=7.95, P\right.$ $<0.01), 2\left(F_{1,1069}=12.55, P<0.01\right), 4\left(F_{1,1065}=6.13\right.$, $P=0.01)$, and $5\left(F_{1,1092}=4.82, P=0.03\right)$ when compared with eutocic cattle. Dystocic animals also tended to spend more time lying per bout on d $3\left(F_{1,1070}=\right.$ $3.64, P=0.06)$ compared with eutocic cows.

\section{Disease Events, Calving Length, Rectal Temperature, and BHB}

Disease Events. No treatment effect was identified on the frequency of disease events (Table 5). Total 

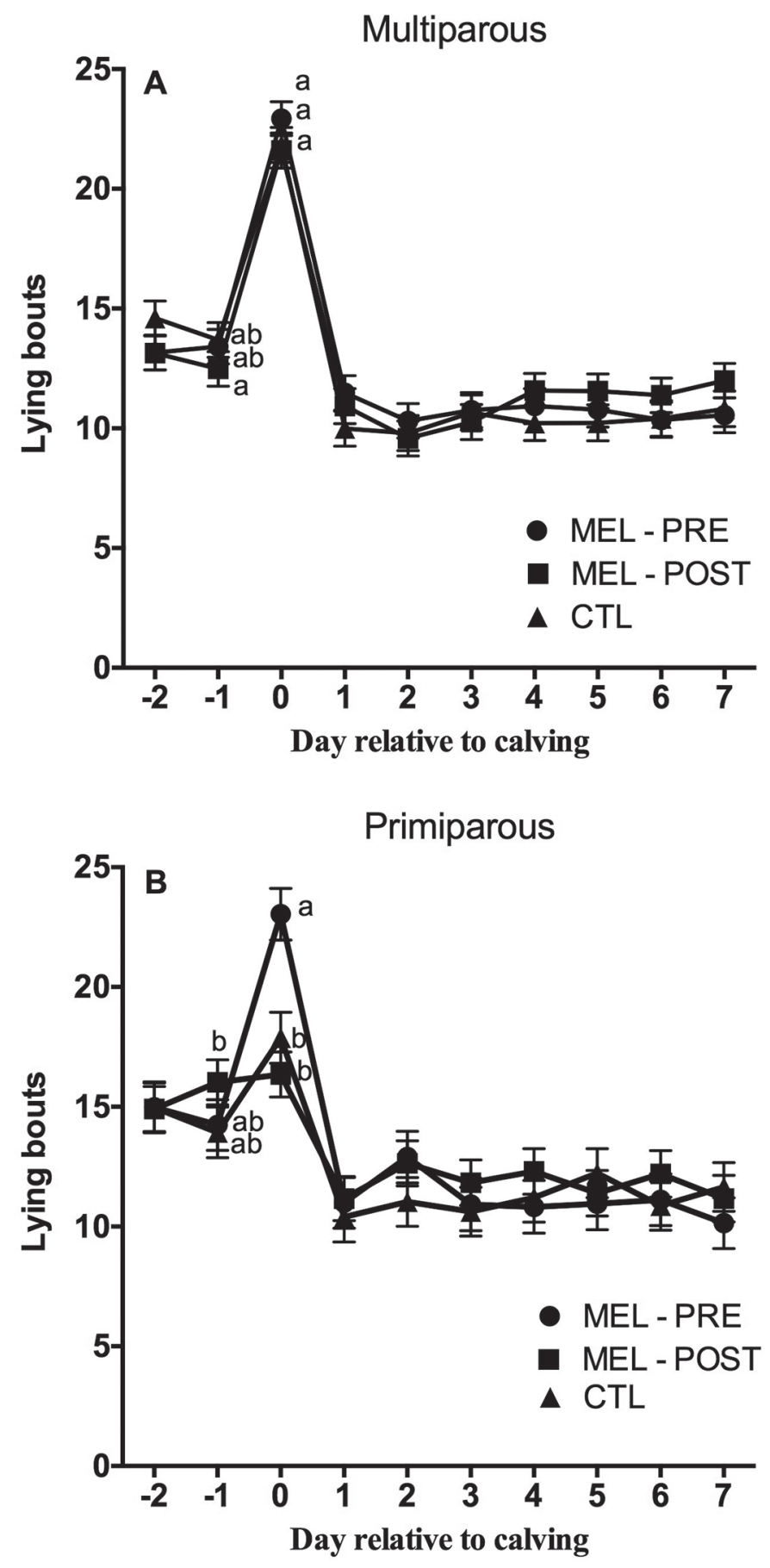

Figure 2. Daily lying bouts (no./d; LSM \pm SE) for the treatment by parity by day interaction term (multiparous, A; primiparous, B), comparisons made within day. Day 0 was designated as the day of calving. Treatments included administration of meloxicam $(1 \mathrm{mg} / \mathrm{kg}$ of BW by mouth) before calving (MEL-PRE; primiparous, $\mathrm{n}=17$; multiparous, $\mathrm{n}=36$ ), after calving (MEL-POST; primiparous, $\mathrm{n}=21$; multiparous, $\mathrm{n}=38$ ), and a negative control (CTL; primiparous, $\mathrm{n}=$ 17; multiparous, $\mathrm{n}=36$ ). Dissimilar letters $(\mathrm{a}, \mathrm{b})$ indicate differences between parity and treatment groups within each day at $P \leq 0.05$ clinical disease events by treatment group were 6 for MEL-PRE, 18 for MEL-POST, and 14 for CTL. No treatment effect was identified on the number of cows with multiple disease events (MEL-PRE, $\mathrm{n}=0$; MELPOST, $\mathrm{n}=2$; and CTL, $\mathrm{n}=3$ ). For cows with multiple disease events, 1 MEL-POST cow had 4 clinical disease events, 1 CTL cow had 3 clinical disease events, 1 MEL-POST cow had 2 clinical disease events, and 2
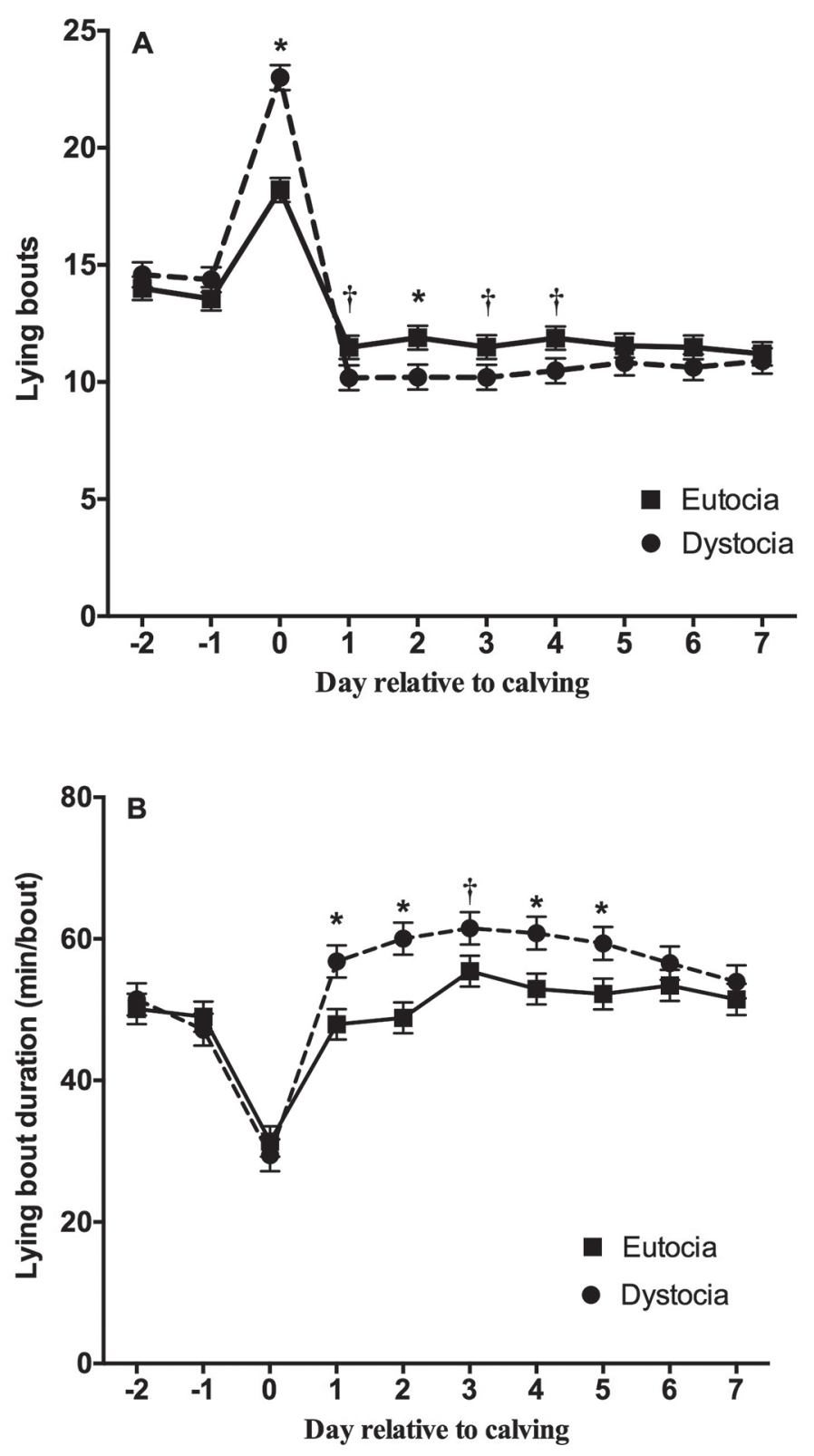

Figure 3. Lying bouts (no./d; LSM \pm SE; A) and lying bout duration (min/bout; LSM $\pm \mathrm{SE}$; B) for the calving difficulty score by day interaction term (eutocia, $\mathrm{n}=96$; dystocia, $\mathrm{n}=69$ ), comparisons made within day. Day 0 was designated as the day of calving. Differences between calving difficulty groups denoted as ${ }^{*} P \leq 0.05$, $\dagger P<0.10$. 
Table 5. Clinical disease incidence by treatment group; data represented as percentage of treatment group, treatments included administration of meloxicam $(1 \mathrm{mg} / \mathrm{kg}$ of BW by mouth) before calving (MEL-PRE, $\mathrm{n}=$ $60)$, after calving (MEL-POST, $\mathrm{n}=69)$, and a negative control (CTL, $\mathrm{n}=65$ )

\begin{tabular}{lcccc}
\hline Disease & MEL-PRE & MEL-POST & CTL & $P$-value \\
\hline Ketosis & 3.3 & 7.3 & 4.6 & 0.66 \\
Milk fever & 1.7 & 2.9 & 3.0 & 1.00 \\
Retained placenta & 3.3 & 8.7 & 6.2 & 0.49 \\
Displaced abomasum & 0.0 & 1.5 & 3.1 & 0.65 \\
Metritis & 1.7 & 4.4 & 0.0 & 0.27 \\
Mastitis & 0.0 & 1.5 & 4.6 & 0.21 \\
Multiple $^{1}$ & 0.0 & 2.9 & 4.6 & 0.33 \\
Dystocia $^{2}$ & 50.0 & 43.5 & 32.2 & 0.12 \\
Stillbirth $^{3}$ & 3.3 & 13.2 & 4.6 & 0.09 \\
\hline
\end{tabular}

${ }^{1}$ Percentage of cows within each treatment group that had more than 1 clinical disease event (ketosis, milk fever, retained placenta, displaced abomasum, metritis, or mastitis) during the first 30 DIM.

${ }^{2}$ Percentage of cows designated as having dystocia (defined as stage 2 of labor was $>70 \mathrm{~min}$ ).

${ }^{3}$ Stillbirth was defined as a calf that was born dead.

CTL cows had 2 clinical disease events. The incidence of dystocia, using calving length as the determining factor, was not different between treatment groups. Moreover, no treatment effect was identified on the frequency of stillborn calves.

Calving Length. Calving length was not different between treatment groups (logarithmic LSM $\pm \mathrm{SE}$; MEL-PRE $=1.94 \pm 0.04$, MEL-POST $=1.89 \pm 0.04$, $\mathrm{CTL}=1.87 \pm 0.04)$. Holstein animals had a longer calving than Jersey animals $(1.95 \pm 0.03$ vs. $1.85 \pm$ $\left.0.04, F_{1,188}=5.32, P=0.02\right)$, whereas primiparous animals had a longer calving than multiparous animals $\left(1.99 \pm 0.03\right.$ vs. $\left.1.81 \pm 0.03, F_{1,188}=19.58, P<0.01\right)$. Animals that received assistance at calving had a longer calving than animals that calved unassisted $(2.11 \pm$ 0.04 vs. $1.69 \pm 0.02, F_{1,188}=72.52, P<0.01$ ).

Rectal Temperature. Treatment did not affect rectal temperature; treatment least squares means \pm standard error were $38.6 \pm 0.03,38.6 \pm 0.03$, and 38.6 $\pm 0.03^{\circ} \mathrm{C}$ for MEL-PRE, MEL-POST, and CTL, respectively. The 3 -way interaction term of breed, calving difficulty score, and day was significant $\left(F_{6,1083}=2.41\right.$, $P=0.03$ ) and was sliced by the 2 -way interaction term, breed by day, to investigate the simple effects of calving difficulty within breed and day. Dystocic Holstein had a higher rectal temperature on $\mathrm{d} 3$ than eutocic Holstein $\left(38.9 \pm 0.05\right.$ vs. $\left.38.7 \pm 0.05^{\circ} \mathrm{C}, F_{1,1021}=8.11, P<0.01\right)$. When compared with eutocic Jersey, dystocic Jersey displayed a higher rectal temperature on d 3 (38.6 \pm 0.09 vs. $\left.38.4 \pm 0.07^{\circ} \mathrm{C}, F_{1,1036}=3.99, P=0.05\right), 4(38.7$ \pm 0.09 vs. $\left.38.5 \pm 0.07^{\circ} \mathrm{C}, F_{1,1020}=4.12, P=0.04\right)$, and $6\left(38.7 \pm 0.09\right.$ vs. $38.5 \pm 0.07^{\circ} \mathrm{C}, F_{1,1020}=5.97, P=$ $0.01)$ after calving.

$\boldsymbol{B H B}$. Treatment did not affect BHB concentration $(\mathrm{MEL}-\mathrm{PRE}=0.78 \pm 0.04 \mathrm{mmol} / \mathrm{L}, \mathrm{MEL}-\mathrm{POST}=0.75$ $\pm 0.04 \mathrm{mmol} / \mathrm{L}$, and $\mathrm{CTL}=0.84 \pm 0.04 \mathrm{mmol} / \mathrm{L})$.

\section{Milk Yield and Components}

Significant main effects and interactions are listed in Table 6. The genetic parameters for MY and milk components were significant in their respective models (daily MY $=$ PTA milk, $\beta=0.0027, P<0.01$; daily fat yield $=$ PTA fat, $\beta=0.0027, P<0.01$; daily protein yield $=$ PTA protein, $\beta=0.0033, P<0.01$; daily lactose yield $=$ PTA milk, $\beta=0.0001, P<0.01$ ).

Daily $M Y$. For daily MY, the treatment by calving difficulty score interaction term was significant $\left(F_{2,232}\right.$ $=3.83, P=0.02)$ and was sliced by calving difficulty score to determine the effect of treatment within calving difficulty (Figure 4). Eutocic MEL-PRE animals produced $6.8 \mathrm{~kg} / \mathrm{d}$ more milk than eutocic CTL $\left(t_{231}\right.$ $=-5.60, P<0.01)$. Eutocic MEL-PRE produced 4.3 $\mathrm{kg} / \mathrm{d}$ more milk than eutocic MEL-POST $\left(t_{232}=-3.42\right.$, $P<0.01)$. Eutocic MEL-POST cows tended to produce more milk then eutocic CTL $\left(t_{233}=2.22, P=0.07\right)$. No differences were found between treatment groups in cattle with dystocia. Regardless of treatment, dystocia did not affect milk yield.

Daily Milk Fat Yield. Treatment effects for milk components are illustrated in Figure 5. For daily milk fat yield, treatment was significant $\left(F_{2,227}=9.15, P\right.$ $<0.01$ ), as MEL-PRE produced $0.16 \mathrm{~kg} / \mathrm{d}$ more fat than CTL $\left(t_{226}=-4.20, P<0.01\right)$. Furthermore, MELPOST animals produced $0.10 \mathrm{~kg} / \mathrm{d}$ more fat than CTL as well $\left(t_{228}=2.79, P=0.02\right)$. No difference was noted between MEL-PRE and MEL-POST.

Daily Milk Protein Yield. For daily milk protein yield, treatment was significant $\left(F_{2,227}=7.07, P<\right.$ $0.01)$, as MEL-PRE produced $0.10 \mathrm{~kg} / \mathrm{d}$ more protein than CTL $\left(t_{227}=-3.76, P<0.01\right)$. However, no difference was found between MEL-POST animals and the CTL or between MEL-PRE and MEL-POST. 
Daily Milk Lactose Yield. For daily milk lactose yield, treatment was significant $\left(F_{2,239}=4.94, P<\right.$ $0.01)$. Similarly to milk protein yield, MEL-PRE animals produced $0.16 \mathrm{~kg} / \mathrm{d}$ more lactose than CTL $\left(t_{239}\right.$ $=-3.14, P<0.01)$. No difference was found between MEL-POST animals and the CTL or between MELPRE and MEL-POST.

\section{DISCUSSION}

Our study is the first study to examine the effect of meloxicam administration before calving on behavioral, health, and production responses in dairy cows. Our results demonstrate that precalving meloxicam administration increased MY in eutocic animals when compared with both eutocic MEL-POST and eutocic CTL. Meloxicam administration had no effect on MY in cattle with dystocia when compared with dystocic CTL animals. However, the effect of meloxicam treatment on behavioral outcomes was less straightforward and difficult to interpret. In fact, whereas meloxicam administration before calving increased MY in eutocic animals, meloxicam administration decreased activity in cattle with dystocia. It is possible that the administration of meloxicam around the time of calving is beneficial to eutocic animals but detrimental to dystocic animals.

\section{Effect of Treatment on Behavioral Responses}

In our study, no treatment effect was identified on activity in eutocic calving events. However, to the best of our knowledge, this is the first study to show that meloxicam administration (both MEL-PRE and MEL-POST) decreased activity in dystocic animals when compared with dystocic CTL animals. Mainau et al. (2014) found that postcalving meloxicam administration to primiparous eutocic animals resulted in an increase in activity for the first $2 \mathrm{~d}$ postcalving when compared with primiparous eutocic controls. Likewise, aspirin administration to eutocic cows increased activity postcalving when compared with eutocic controls (Barragan et al., 2017b). We anticipated that meloxicam treatment would increase activity postcalving regardless of calving difficulty; however, our results oppose our original hypothesis. In human studies, women who had chronic insomnia after childbirth reported higher levels of bodily pain (Sivertsen et al., 2017), and NSAID therapy administered within $24 \mathrm{~h}$ of childbirth helped alleviate this pain (Hedayati et al., 2003). It is possible that in the present study administration of meloxicam to dystocic animals reduced activity by alleviating inflammation, allowing the cow to rest more easily, similar to Barrier et al. (2014), where meloxicam administration increased lying time after caesarean sections in beef cattle. Nevertheless, this is merely speculation, and additional studies investigating the effect of administering meloxicam to dystocic animals on locomotor and lying behaviors in periparturient cows may reveal interesting findings.

In first-lactation animals, primiparous MEL-PRE had more lying bouts on the day of calving when compared with primiparous CTL as well as when compared with primiparous MEL-POST. Similarly, beef cows receiving

Table 6. Probability level for main effects and interaction terms for daily milk yield and components (kg/d) averaged by week for the first 15 wk of lactation for 194 cows receiving meloxicam before calving (MEL-PRE, $\mathrm{n}=60$ ), after calving (MEL-POST, $\mathrm{n}=69$ ), or a negative control $(\mathrm{CTL}, \mathrm{n}=65)$

\begin{tabular}{|c|c|c|c|c|}
\hline Fixed effect & Daily milk yield & Daily fat yield & Daily protein yield & Daily lactose yield \\
\hline$\overline{\text { PTA milk }}{ }^{1}$ & $<0.01$ & $\mathrm{NA}^{2}$ & NA & $<0.01$ \\
\hline PTA fat ${ }^{1}$ & NA & $<0.01$ & $\mathrm{NA}$ & NA \\
\hline PTA protein ${ }^{1}$ & NA & NA & $<0.01$ & $\mathrm{NA}$ \\
\hline Breed & $<0.01$ & $<0.01$ & $<0.01$ & $<0.01$ \\
\hline Parity & $<0.01$ & $<0.01$ & $<0.01$ & $<0.01$ \\
\hline Calving difficulty & 0.36 & $-^{3}$ & - & - \\
\hline Breed $\times$ week & $<0.01$ & $<0.01$ & - & $<0.01$ \\
\hline Parity $\times$ week & $<0.01$ & $<0.01$ & $<0.01$ & $<0.01$ \\
\hline
\end{tabular}

${ }^{1}$ The genetic parameter for milk yield (PTA milk) was only included in the daily milk yield and lactose models. The genetic parameter for fat yield (PTA fat) was only included in the daily fat yield model. The genetic parameter for protein yield (PTA protein) was only included in the daily protein model.

${ }^{2} \mathrm{NA}=$ not applicable.

${ }^{3}$ Dashed line represents a term that was not significant for that specific model $(P>0.05)$ and therefore was removed during backward elimination. Terms that were not significant for any of the milk yield and component models were removed during backward elimination and are not included in the table. 


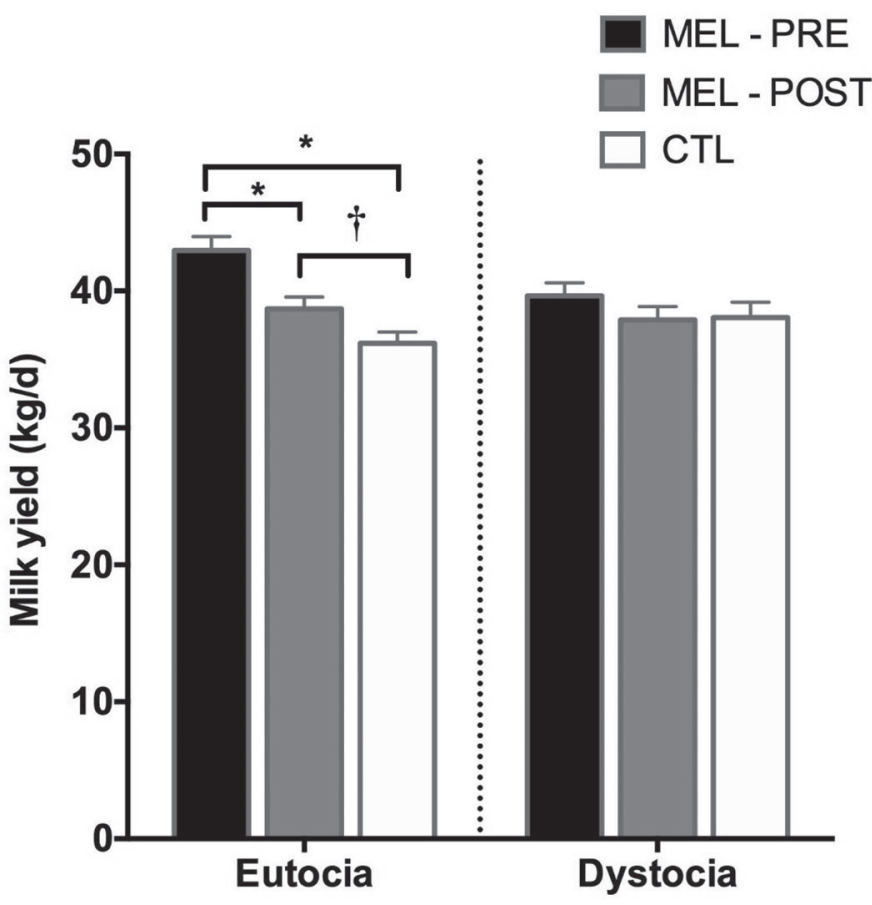

Figure 4. Daily milk yield $(\mathrm{kg} / \mathrm{d} ; \mathrm{LSM} \pm \mathrm{SE})$ for the treatment by calving difficulty score interaction term with comparisons made within calving difficulty. Milk yield was measured for the first $15 \mathrm{wk}$ of lactation. Treatments included administration of meloxicam $(1 \mathrm{mg} /$ $\mathrm{kg}$ of BW by mouth) before calving (MEL-PRE), after calving (MELPOST), and a negative control (CTL). Sample sizes for eutocia were MEL-PRE, $\mathrm{n}=30$, MEL-POST, $\mathrm{n}=39$, and CTL, $\mathrm{n}=44$; and for dystocia were MEL-PRE, $\mathrm{n}=30$, MEL-POST, $\mathrm{n}=30$, and CTL, $\mathrm{n}$ $=21$. Differences between treatment groups denoted as ${ }^{*} P \leq 0.05, \dagger P$ $<0.10$.

meloxicam before caesarean section displayed more lying bouts during the 24-h period following surgery than beef cows that received a placebo before surgery (Barrier et al., 2014). We are unsure as to why meloxicam administration before calving increased lying bouts on the day of calving in heifers and why this effect was limited to primiparous animals and not apparent in multiparous cows. It is interesting that the number of lying bouts on the day of calving in the primiparous precalving meloxicam group was more similar to that of the multiparous animals. As multiparous animals typically deliver calves more easily than primiparous animals, these data could suggest that the anti-inflammatory effects of precalving meloxicam administration to primiparous animals allowed for an easier calving, or a calving more similar to that of a multiparous cow.

\section{Effect of Calving Difficulty on Behavioral Responses}

In the present study, dystocic cows were less active during some of the days following calving when compared with eutocic cows, in agreement with a past
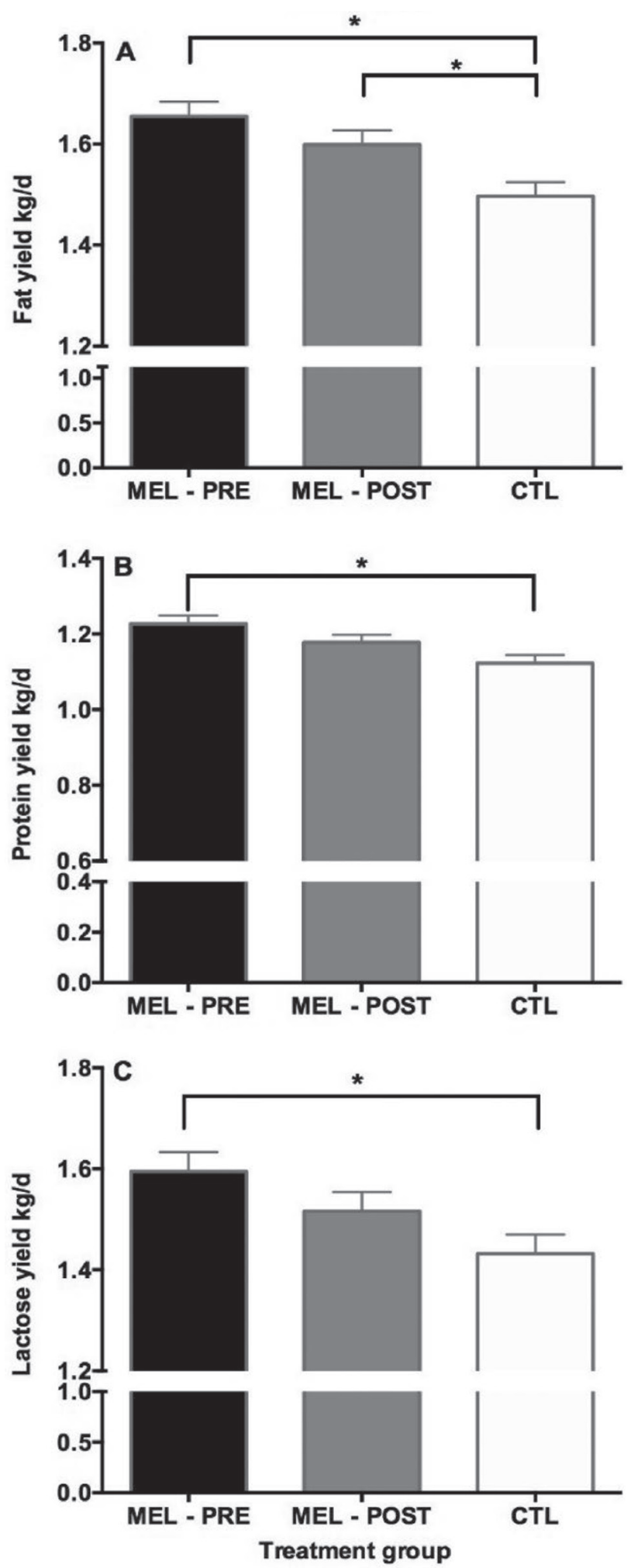

Figure 5. Daily milk fat $(\mathrm{kg} / \mathrm{d} ; \mathrm{LSM} \pm \mathrm{SE} ; \mathrm{A})$, protein (B), and lactose $(\mathrm{C})$ measured for the first $15 \mathrm{wk}$ of lactation. Treatments included administration of meloxicam ( $1 \mathrm{mg} / \mathrm{kg}$ of BW by mouth) before calving (MEL-PRE, $\mathrm{n}=60$ ), after calving (MEL-POST, $\mathrm{n}=69$ ), and a negative control $(\mathrm{CTL}, \mathrm{n}=65)$. Differences between treatment groups are denoted as $* P \leq 0.05$. 
study (Barragan et al., 2017b). A reduction in locomotor behavior following dystocia is not surprising, as diseases such as metritis, retained fetal membranes, and subclinical ketosis have been shown to reduce postpartum activity as well (Liboreiro et al., 2015). In our study, dystocic cows had 5 more lying bouts on the day of calving than eutocic cows. Dystocic cows also had a reduction of approximately 1 to 2 bouts on $d 2$ and spent approximately 10 more min lying per bout for the first few days after calving when compared with eutocic cows. These data suggest that dystocia increases restlessness around the time of calving, as seen in previous studies (Proudfoot et al., 2009; Yeiser, 2011; Barrier et al., 2012), and that the inflammation associated with dystocia after calving decreases activity and reduces the motivation to rise from a lying state resulting in fewer lying bouts with a longer duration.

\section{Effect of Treatment on the Frequency of Disease Events, Calving Length, and BHB}

Our study failed to identify any treatment effect on any of the health outcomes measured, similar to past postpartum meloxicam cow studies (Newby et al., 2013; Mainau et al., 2014; Carpenter et al., 2016). Both MELPRE and MEL-POST groups had similar BHB concentrations as controls, comparable to previous meloxicam studies (Newby et al., 2013; Carpenter et al., 2016). Our study also failed to identify a treatment effect on the frequency of disease events; however, it should be noted that our study had relatively few disease events. This is likely because the Virginia Tech dairy facility was just built in 2015, 1 yr before the beginning of the experiment, and that this modern facility may have improved the well-being of the herd.

Other NSAID studies have yielded negative results on health outcomes. We hypothesized that the mode of action of each NSAID and the timing of NSAID administration may have been contributing to the differences noted between studies. For instance, flunixin meglumine, an NSAID with greater anti-cyclooxygenase (COX)-1 activity than most NSAID (Beretta et al., 2005), increased the risk for retained placenta, elevated temperature, and metritis when administered approximately 1 $\mathrm{h}$ after calving when compared with controls (Newby et al., 2017). Furthermore, when flunixin meglumine was administered just before calving, a large increase in the incidence of stillborn calves was seen (Newby et al., 2017). Moreover, precalving administration of lysine acetylsalicylate (acetylsalicylic acid), which irreversibly binds to COX-1 (Vane and Botting, 2003), increased the incidence of retained placenta when compared with controls (Grossi et al., 2013). However, when salicylate derivatives were administered 12 or more hours after calving, no effect was noted on the frequency of disease events (Carpenter et al., 2016; Barragan et al., 2017b). Meloxicam, a preferential COX-2 inhibitor, has no apparent negative effect on the frequency of disease events regardless of the time of administration (Newby et al., 2013, 2014; Mainau et al., 2014; Carpenter et al., 2016), and precalving administration in the present study did not affect the incidence of stillborn calves or the frequency of disease events. These data suggest that NSAID with a greater affinity for COX-1, such as salicylate derivatives and flunixin meglumine, may need to be administered at least $12 \mathrm{~h}$ after calving to avoid adverse effects on the incidence of disease events. However, the administration of a COX-2 preferential inhibitor, such as meloxicam, may be safer to administer before or just after calving.

Reproductive physiologists, however, have argued that COX-2 is a critical enzyme for parturition (Shenavai et al., 2012). During initiation of parturition, cortisol induces an upregulation of COX-2 expression (Whittle et al., 2000) before luteolysis, suggesting that COX-2 increases $\mathrm{PGF}_{2 \alpha}$ concentrations, which initiates parturition through lysing of the corpus luteum and causing the withdrawal of progesterone (Schuler et al., 2006). Therefore, inhibition of COX-2 via meloxicam administration before calving could, in theory, cause dystocia. Our study did not identify an effect of precalving meloxicam administration on calving length or the incidence of dystocia. It is possible that meloxicam was not administered in a large enough dose or early enough in the initiation of parturition phase to elicit this effect. We would also note that meloxicam administration after calving has not been associated with a higher incidence of reproductive diseases, such as retained placenta and metritis, as flunixin meglumine has. It seems likely that the mode of action of each NSAID is playing a larger role than previously thought. Additional studies detailing the initiation of parturition and the role of the COX enzymes in the bovine may provide clarity as well as pharmacodynamic studies examining the mechanism of meloxicam.

\section{Effect of Treatment on Milk Yield and Milk Components}

In our study, eutocic animals that received meloxicam before calving produced $6.8 \mathrm{~kg} / \mathrm{d}$ more milk for the first 15 wk of lactation when compared with eutocic controls. Whereas this treatment effect appears large, it is not without precedent. In multiparous animals, past studies have demonstrated that meloxicam administration after calving increases daily MY by $4 \mathrm{~kg} / \mathrm{d}$ (Carpenter et al., 2016), and sodium salicylate increased daily MY by approximately $8 \mathrm{~kg} / \mathrm{d}$ (Farney et al., 2013) when 
compared with controls. Furthermore, in our study, precalving meloxicam administration increased daily milk fat, protein, and lactose yield, regardless of calving difficulty, when compared with controls. A similar effect was seen in Carpenter et al. (2016), where postcalving meloxicam administration increased milk protein yield. However, other meloxicam studies have failed to identify a milk response to treatment, but those studies only measured MY during the first $30 \mathrm{~d}$ after calving (Mainau et al., 2014) or just in assisted calving events (Newby et al., 2013). Past research reported that NSAID treatment effect on MY is accentuated during peak lactation (Trevisi and Bertoni, 2008; Carpenter et al., 2016). Therefore, in our study, MY was measured for the first 15 wk of lactation. Additionally, in our study, meloxicam was dosed at $1 \mathrm{mg} / \mathrm{kg}$ of BW by mouth, similar to Carpenter et al. (2016), whereas other studies administered meloxicam at $0.5 \mathrm{mg} / \mathrm{kg}$ of BW subcutaneously (Newby et al., 2013; Mainau et al., 2014). This could also explain why our treatment effect is more similar to that of Carpenter et al. (2016) than of that in the other studies.

Other NSAID studies in peripartum cows have yielded highly variable results on milk production, with some studies demonstrating an increase as much as 8 $\mathrm{kg} / \mathrm{d}$ in multiparous cows and other studies indicating a decline in production. This variable response may be due in part to the duration of milk production measurement. Mature cows treated with sodium salicylate have produced 3.5 to $8 \mathrm{~kg} / \mathrm{d}$ more milk (Farney et al., 2013; Carpenter et al., 2016), as well as more milk fat (Farney et al., 2013) and milk protein (Carpenter et al., 2016), during a 305-d lactation when compared with controls, with the majority of this increase noted during peak lactation (Carpenter et al., 2016). Likewise, administration of acetylsalicylic acid after calving increased milk by $1 \mathrm{~kg} / \mathrm{d}$ for the first 5 mo of lactation in organic herds (Barragan et al., 2017a), and another aspirin study demonstrated a $13 \%$ increase in peak MY (Trevisi and Bertoni, 2008). However, other NSAID studies have not identified a positive milk response to treatment. Cows treated with flunixin meglumine produced $3.5 \mathrm{~kg} / \mathrm{d}$ less milk during the first week of lactation when compared with controls (Shwartz et al., 2009). Likewise, Newby et al. (2017) found that flunixin-treated cows produced $1.6 \mathrm{~kg} / \mathrm{d}$ less milk for the first 2 wk of lactation when compared with controls. In New Zealand, the administration of carprofen after calving did not elicit a milk response (Meier et al., 2014). However, Meier et al. (2014) recorded MY for the first 6 wk after calving, whereas recent studies have reported that the effect of NSAID therapy may not become apparent until later in lactation (Carpenter et al., 2016).
Considering the aforementioned studies collectively, we speculated that measuring MY through peak lactation was key to identifying a response to NSAID treatment (Carpenter et al., 2016). One possible explanation for the increase in peak MY may be due to alterations in mammary epithelial cell number (e.g., either an increase in cell proliferation or a decrease in involution/apoptosis). Indeed, in mice, inflammatory signaling impaired milk secretion due to an amplified rate of apoptosis in the mammary epithelium as a result of nuclear factor (NF)- $\mathrm{BB}$ activation (Connelly et al., 2010). Accordingly, in mice, reduced activity of NF- $\kappa B$, via knockout of IKK $\beta$ (an upstream regulator of NF$\kappa \mathrm{B}$ ), resulted in a delay in involution and a reduction of apoptotic cells in the mammary gland (Baxter et al., 2006). In the bovine, cows displaying the greatest degree of inflammation produced $20 \%$ less milk than cows with the least degree of inflammation (Bertoni et al., 2008). However, the mechanistic question of how inflammation affects the mammary epithelium and milk secretion in the bovine has yet to be answered. In our study, we speculated that precalving administration of meloxicam to eutocic cows impaired inflammation associated with parturition, which led to an increase in MY. However, when meloxicam was administered after calving, the inflammatory cascade was already sufficiently initiated by parturition; therefore, a belated treatment would have a smaller effect. Nevertheless, we can only speculate on the effect of NSAID therapy on the bovine mammary epithelium. Additional studies examining the rate of cell proliferation and apoptosis in the bovine mammary epithelium are needed.

We hypothesized that administration of meloxicam around the time of calving would be a more efficacious treatment in dystocic cows than eutocic cows; however, our results for MY demonstrated the opposite response, as precalving treatment increased MY for eutocic cows but not for dystocic cows. Our study confirms the findings of Newby et al. (2013), where meloxicam treatment did not elicit a milk response in cows with dystocia. The reason for this effect may be that the dose of meloxicam administered to dystocic animals was insufficient, and that those cows may require larger doses or administration of the drug more than once, as only a single dose was administered in the present study. We anticipated treatment would be more efficacious in dystocic cows because past studies have demonstrated an improvement in performance following NSAID therapy for disease events such as mastitis (McDougall et al., 2009, 2016; Yeiser et al., 2012), lameness (Wagner et al., 2017), metritis (Amiridis et al., 2001), and subclinical endometritis (Priest et al., 2013). However, in a review on dystocia, Mee (2008) 
eloquently paraphrases McClintock (2004): "There is no such thing as an easy calving...just varying degrees of difficulty... from the dam's perspective." In fact, an inflammatory response has been documented in seemingly healthy cattle after calving (Humblet et al., 2006; Bionaz et al., 2007; Graugnard et al., 2012; Mullins et al., 2012), suggesting that nearly all cattle experience inflammation due to parturition (Bradford et al., 2015). Therefore, administration of meloxicam to peripartum cows may only be effective in improving MY for those animals experiencing a reduced state of inflammation. Additional studies examining treatments for cows with dystocia are warranted.

\section{Limitations}

The definition of dystocia (calving length in the present study versus intervention in other studies) may be a contributing factor in explaining the differences between studies when examining the effects of treatment, calving difficulty, and the treatment by calving difficulty interaction on behavioral and production responses. Therefore, comparisons drawn across studies should be done with caution. We chose calving length to define dystocia to remove subjectivity from the dystocia definition. However, we also acknowledge that calving length is a considerably more liberal definition.

Lastly, we acknowledge a major limitation of precalving meloxicam administration for the widespread application in the dairy industry. In our study, 237 cows were enrolled; however, only 194 cows were used for analysis. A large portion of this was due to cows not receiving the precalving treatment or not receiving precalving treatment within the specified timeframes, because the accuracies of calving identification technologies are still moderate at best. Although improving the accuracy of calving identification is beyond the scope of the current project, the application of the administration of meloxicam before calving may be problematic in industry until the accuracy of these technologies have been improved. Recent advances in identifying the onset of calving utilizing either ruminating, lying, or activity behaviors (Borchers et al., 2017; Mahmoud et al., 2017) create optimism in making this treatment regimen a possibility in the dairy industry.

\section{CONCLUSIONS}

This is the first study to demonstrate an improvement in MY in eutocic cows that were treated with meloxicam before calving. Furthermore, our study confirms that difficult calving events increase lying bouts on the day of calving and decreases activity thereafter.
We believe this is the first study to demonstrate that dystocia decreases lying bouts and increases lying bout duration in the days following calving. Additional research studies examining intervention strategies for cattle with dystocia are still needed.

\section{ACKNOWLEDGMENTS}

Financial support for the primary author (T. H. Swartz) was provided by the Virginia Tech College of Agriculture and Life Sciences Graduate Research Assistantship. The authors recognize M. Ellett Jr. and K. McCauley for their assistance in data collection, M. McGilliard and R. White for their statistical expertise, and the farm staff at the Virginia Tech dairy facility for their support.

\section{REFERENCES}

Amiridis, G. S., L. Leontides, E. Tassos, P. Kostoulas, and G. C. Fthenakis. 2001. Flunixin meglumine accelerates uterine involution and shortens the calving-to-first-oestrus interval in cows with puerperal metritis. J. Vet. Pharmacol. Ther. 24:365-367.

Atashi, H., A. R. Abdolmohammadi, A. Asaadi, A. Akhlaghi, M. Dadpasand, and Y. J. Ahangari. 2012. Using an incomplete gamma function to quantify the effect of dystocia on the lactation performance of Holstein dairy cows in Iran. J. Dairy Sci. 95:2718-2722.

Bach, K. D., W. Heuwieser, and J. A. A. McArt. 2016. Technical note: Comparison of 4 electronic handheld meters for diagnosing hyperketonemia in dairy cows. J. Dairy Sci. 99:9136-9142.

Barragan, A. A., L. M. Bauman, L. d. Costa, J. Velez, J. D. R. Gonzalez, G. M. Schuenemann, and S. Bas. 2017a. Effects of oral administration of acetylsalicylic acid after parturition on milk yield and milk components in lactating dairy cows under certified organic management. J. Dairy Sci. 100(Suppl. 2):176-177. (Abstr.)

Barragan, A. A., L. M. Bauman, J. Velez, J. D. R. Gonzalez, G. M. Schuenemann, and S. Bas. 2017b. Effects of oral administration of acetylsalicylic acid after parturition on activity patterns, prevalence of diseases, mortality and culling rates in dairy cows. J. Dairy Sci. 100(Suppl. 2):17. (Abstr.)

Barrier, A. C., T. M. Coombs, C. M. Dwyer, M. J. Haskell, and L. Goby. 2014. Administration of a NSAID (meloxicam) affects lying behaviour after caesarean section in beef cows. Appl. Anim. Behav. Sci. 155:28-33.

Barrier, A. C., M. J. Haskell, A. I. Macrae, and C. M. Dwyer. 2012. Parturition progress and behaviours in dairy cows with calving difficulty. Appl. Anim. Behav. Sci. 139:209-217.

Baxter, F. O., P. J. Came, K. Abell, B. Kedjouar, M. Huth, K. Rajewsky, M. Pasparakis, and C. J. Watson. 2006. IKKbeta/2 induces TWEAK and apoptosis in mammary epithelial cells. Development 133:3485-3494.

Beretta, C., G. Garavaglia, and M. Cavalli. 2005. COX-1 and COX-2 inhibition in horse blood by phenylbutazone, flunixin, carprofen and meloxicam: An in vitro analysis. Pharmacol. Res. 52:302-306.

Bertoni, G., E. Trevisi, X. Han, and M. Bionaz. 2008. Effects of inflammatory conditions on liver activity in puerperium period and consequences for performance in dairy cows. J. Dairy Sci. 91:33003310 .

Bionaz, M., E. Trevisi, L. Calamari, F. Librandi, A. Ferrari, and G. Bertoni. 2007. Plasma paraoxonase, health, inflammatory conditions, and liver function in transition dairy cows. J. Dairy Sci. 90:1740-1750.

Borchers, M. R., Y. M. Chang, K. L. Proudfoot, B. A. Wadsworth, A. E. Stone, and J. M. Bewley. 2017. Machine-learning-based calving 
prediction from activity, lying, and ruminating behaviors in dairy cattle. J. Dairy Sci. 100:5664-5674.

Bradford, B. J., K. Yuan, J. K. Farney, L. K. Mamedova, and A. J. Carpenter. 2015. Invited review: Inflammation during the transition to lactation: New adventures with an old flame. J. Dairy Sci. 98:6631-6650.

Burfeind, O., V. S. Suthar, R. Voigtsberger, S. Bonk, and W. Heuwieser. 2011. Validity of prepartum changes in vaginal and rectal temperature to predict calving in dairy cows. J. Dairy Sci. 94:5053-5061.

Carpenter, A. J., C. M. Ylioja, C. F. Vargas, L. K. Mamedova, L. G. Mendonca, J. F. Coetzee, L. C. Hollis, R. Gehring, and B. J. Bradford. 2016. Hot topic: Early postpartum treatment of commercial dairy cows with nonsteroidal antiinflammatory drugs increases whole-lactation milk yield. J. Dairy Sci. 99:672-679.

Coetzee, J. F. 2013. A review of analgesic compounds used in food animals in the United States. Vet. Clin. North Am. Food Anim. Pract. 29:11-28.

Connelly, L., W. Barham, R. Pigg, L. Saint-Jean, T. Sherrill, D. S. Cheng, L. A. Chodosh, T. S. Blackwell, and F. E. Yull. 2010. Activation of nuclear factor kappa B in mammary epithelium promotes milk loss during mammary development and infection. J. Cell. Physiol. 222:73-81.

Correa, M. T., H. Erb, and J. Scarlett. 1993. Path analysis for seven postpartum disorders of Holstein cows. J. Dairy Sci. 76:1305-1312.

Dematawewa, C. M., and P. J. Berger. 1997. Effect of dystocia on yield, fertility, and cow losses and an economic evaluation of dystocia scores for Holsteins. J. Dairy Sci. 80:754-761.

Farney, J. K., L. K. Mamedova, J. F. Coetzee, J. E. Minton, L. C. Hollis, and B. J. Bradford. 2013. Sodium salicylate treatment in early lactation increases whole-lactation milk and milk fat yield in mature dairy cows. J. Dairy Sci. 96:7709-7718.

Ferguson, J. D., D. T. Galligan, and N. Thomsen. 1994. Principal descriptors of body condition score in Holstein cows. J. Dairy Sci. 77:2695-2703.

Goff, J. P. 2006. Major advances in our understanding of nutritional influences on bovine health. J. Dairy Sci. 89:1292-1301.

Gorden, P. J., M. Burchard, J. A. Ydstie, M. D. Kleinhenz, L. W Wulf, S. J. Rajewski, C. Wang, R. Gehring, J. P. Mochel, and J. F. Coetzee. 2018. Comparison of milk and plasma pharmacokinetics of meloxicam in postpartum versus mid-lactation Holstein cows. J. Vet. Pharmacol. Ther. 41:463-468.

Graugnard, D. E., M. Bionaz, E. Trevisi, K. M. Moyes, J. L. SalakJohnson, R. L. Wallace, J. K. Drackley, G. Bertoni, and J. J. Loor. 2012. Blood immunometabolic indices and polymorphonuclear neutrophil function in peripartum dairy cows are altered by level of dietary energy prepartum. J. Dairy Sci. 95:1749-1758.

Grossi, P., G. Bertoni, F. P. Cappelli, and E. Trevisi. 2013. Effects of the precalving administration of omega- 3 fatty acids alone or in combination with acetylsalicylic acid in periparturient dairy cows. J. Anim. Sci. 91:2657-2666.

Hedayati, H., J. Parsons, and C. A. Crowther. 2003. Rectal analgesia for pain from perineal trauma following childbirth. Cochrane Database Syst. Rev. 2003:CD003931.

Humblet, M. F., H. Guyot, B. Boudry, F. Mbayahi, C. Hanzen, F. Rollin, and J. M. Godeau. 2006. Relationship between haptoglobin, serum amyloid A, and clinical status in a survey of dairy herds during a 6-month period. Vet. Clin. Pathol. 35:188-193.

Huzzey, J. M., T. F. Duffield, S. J. LeBlanc, D. M. Veira, D. M. Weary, and M. A. von Keyserlingk. 2009. Short communication: Haptoglobin as an early indicator of metritis. J. Dairy Sci. 92:621-625.

Kaniyamattam, K., and A. De Vries. 2014. Agreement between milk fat, protein, and lactose observations collected from the Dairy Herd Improvement Association (DHIA) and a real-time milk analyzer. J. Dairy Sci. 97:2896-2908.

Kelton, D. F., K. D. Lissemore, and R. E. Martin. 1998. Recommendations for recording and calculating the incidence of selected clinical diseases of dairy cattle. J. Dairy Sci. 81:2502-2509.

Kenward, M. G., and J. H. Roger. 1997. Small sample inference for fixed effects from restricted maximum likelihood. Biometrics 53:983-997.
Liboreiro, D. N., K. S. Machado, P. R. B. Silva, M. M. Maturana, T. K. Nishimura, A. P. Brandão, M. I. Endres, and R. C. Chebel 2015. Characterization of peripartum rumination and activity of cows diagnosed with metabolic and uterine diseases. J. Dairy Sci. 98:6812-6827.

Lombard, J. E., F. B. Garry, S. M. Tomlinson, and L. P. Garber. 2007. Impacts of dystocia on health and survival of dairy calves. J. Dairy Sci. 90:1751-1760.

Mahmoud, F., B. Christopher, A. Maher, H. Jürg, S. Alexander, S. Adrian, and H. Gaby. 2017. Prediction of calving time in dairy cattle. Anim. Reprod. Sci. 187:37-46.

Mainau, E., A. Cuevas, J. L. Ruiz-de-la-Torre, E. Abbeloos, and X. Manteca. 2014. Effect of meloxicam administration after calving on milk production, acute phase proteins, and behavior in dairy cows. J. Vet. Behav.: Clin. Appl. Res. 9:357-363. https://doi.org/ 10.1016/j.jveb.2014.07.007.

Malreddy, P. R., J. F. Coetzee, B. Kukanich, and R. Gehring. 2013. Pharmacokinetics and milk secretion of gabapentin and meloxicam co-administered orally in Holstein-Friesian cows. J. Vet. Pharmacol. Ther. 36:14-20.

McClintock, S. E. J. 2004. A genetic evaluation of dystocia in Australian Holstein-Friesian cattle. University of Melbourne, Institute of Land and Food Resources.

McDougall, S., E. Abbeloos, S. Piepers, A. S. Rao, S. Astiz, T. van Werven, J. Statham, and N. Perez-Villalobos. 2016. Addition of meloxicam to the treatment of clinical mastitis improves subsequent reproductive performance. J. Dairy Sci. 99:2026-2042.

McDougall, S., M. A. Bryan, and R. M. Tiddy. 2009. Effect of treatment with the nonsteroidal antiinflammatory meloxicam on milk production, somatic cell count, probability of re-treatment, and culling of dairy cows with mild clinical mastitis. J. Dairy Sci. 92:4421-4431.

Mee, J. F. 2008. Prevalence and risk factors for dystocia in dairy cattle: A review. Vet. J. 176:93-101.

Meier, S., N. V. Priest, C. R. Burke, J. K. Kay, S. McDougall, M. D. Mitchell, C. G. Walker, A. Heiser, J. J. Loor, and J. R. Roche. 2014. Treatment with a nonsteroidal antiinflammatory drug after calving did not improve milk production, health, or reproduction parameters in pasture-grazed dairy cows. J. Dairy Sci. 97:29322943.

Meyer, C. L., P. J. Berger, K. J. Koehler, J. R. Thompson, and C. G. Sattler. 2001. Phenotypic trends in incidence of stillbirth for Holsteins in the United States. J. Dairy Sci. 84:515-523.

Mullins, C. R., L. K. Mamedova, M. J. Brouk, C. E. Moore, H. B. Green, K. L. Perfield, J. F. Smith, J. P. Harner, and B. J. Bradford. 2012. Effects of monensin on metabolic parameters, feeding behavior, and productivity of transition dairy cows. J. Dairy Sci. 95:1323-1336.

Newby, N. C., K. E. Leslie, H. D. Dingwell, D. F. Kelton, D. M. Weary, L. Neuder, S. T. Millman, and T. F. Duffield. 2017. The effects of periparturient administration of flunixin meglumine on the health and production of dairy cattle. J. Dairy Sci. 100:582-587.

Newby, N. C., D. L. Pearl, S. J. LeBlanc, K. E. Leslie, M. A. G. von Keyserlingk, and T. F. Duffield. 2013. Effects of meloxicam on milk production, behavior, and feed intake in dairy cows following assisted calving. J. Dairy Sci. 96:3682-3688.

Newby, N. C., D. Renaud, R. Tremblay, and T. F. Duffield. 2014. Evaluation of the effects of treating dairy cows with meloxicam at calving on retained fetal membranes risk. Can. Vet. J. 55:11961199 .

NRC. 2001. Nutrient Requirements of Dairy Cattle. 7th ed. Natl. Acad. Press, Washington, DC.

Ouellet, V., E. Vasseur, W. Heuwieser, O. Burfeind, X. Maldague, and E. Charbonneau. 2016. Evaluation of calving indicators measured by automated monitoring devices to predict the onset of calving in Holstein dairy cows. J. Dairy Sci. 99:1539-1548.

Pohl, A., O. Burfeind, and W. Heuwieser. 2015. The associations between postpartum serum haptoglobin concentration and metabolic status, calving difficulties, retained fetal membranes, and metritis. J. Dairy Sci. 98:4544-4551. 
Priest, N. V., S. McDougall, C. R. Burke, J. R. Roche, M. Mitchell, K. L. McLeod, S. L. Greenwood, and S. Meier. 2013. The responsiveness of subclinical endometritis to a nonsteroidal antiinflammatory drug in pasture-grazed dairy cows. J. Dairy Sci. 96:4323-4332.

Proudfoot, K. L., J. M. Huzzey, and M. A. G. von Keyserlingk. 2009. The effect of dystocia on the dry matter intake and behavior of Holstein cows. J. Dairy Sci. 92:4937-4944.

Qu, Y., A. N. Fadden, M. G. Traber, and G. Bobe. 2014. Potential risk indicators of retained placenta and other diseases in multiparous cows. J. Dairy Sci. 97:4151-4165.

Saint-Dizier, M., and S. Chastant-Maillard. 2015. Methods and onfarm devices to predict calving time in cattle. Vet. J. (London) 205:349-356.

Schuenemann, G. M., I. Nieto, S. Bas, K. N. Galvao, and J. Workman. 2011. Assessment of calving progress and reference times for obstetric intervention during dystocia in Holstein dairy cows. J. Dairy Sci. 94:5494-5501

Schuler, G., U. Teichmann, M. P. Kowalewski, B. Hoffmann, E. Madore, M. A. Fortier, and K. Klisch. 2006. Expression of cyclooxygenase-II (COX-II) and 20 $\alpha$-hydroxysteroid dehydrogenase

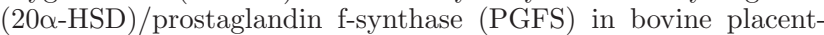
omes: Implications for the initiation of parturition in cattle. Placenta 27:1022-1029.

Shenavai, S., S. Preissing, B. Hoffmann, M. Dilly, C. Pfarrer, G. R. Ozalp, C. Caliskan, K. Seyrek-Intas, and G. Schuler. 2012. Investigations into the mechanisms controlling parturition in cattle. Reproduction 144:279-292.

Shwartz, G., K. L. Hill, M. J. VanBaale, and L. H. Baumgard. 2009. Effects of flunixin meglumine on pyrexia and bioenergetic variables in postparturient dairy cows. J. Dairy Sci. 92:1963-1970.

Sivertsen, B., K. J. Petrie, J. C. Skogen, M. Hysing, and M. EberhardGran. 2017. Insomnia before and after childbirth: The risk of developing postpartum pain-A longitudinal population-based study. Eur. J. Obstet. Gynecol. Reprod. Biol. 210:348-354.
Sordillo, L. M., and W. Raphael. 2013. Significance of metabolic stress, lipid mobilization, and inflammation on transition cow disorders. Vet. Clin. North Am. Food Anim. Pract. 29:267-278.

Trevisi, E., and G. Bertoni. 2008. Attenuation with acetylsalicylate treatments of inflammatory conditions in periparturient dairy cows. Pages $22-37$ in Aspirin and Health Research Progress. P. I. Quinn, ed. Nova Science Publishers, Hauppauge, NY.

USDA-APHIS. 2008. Dairy 2007 Part II: Changes in the U.S. Dairy Cattle Industry, 1991-2007. USDA, Washington, DC.

USDA-APHIS. 2010. Heifer Calf Health and Management Practices on U.S. Dairy Operations, 2007. USDA, Washington, DC.

Vane, J. R., and R. M. Botting. 2003. The mechanism of action of aspirin. Thromb. Res. 110:255-258.

Wagner, S. A., J. M. Young, J. K. Tena, and B. H. Manning. 2017. Short communication: Behavioral evaluation of the analgesic effect of flunixin meglumine in lame dairy cows. J. Dairy Sci. 100:65626566 .

Weary, D. M., J. M. Huzzey, and M. A. von Keyserlingk. 2009. Boardinvited review: Using behavior to predict and identify ill health in animals. J. Anim. Sci. 87:770-777.

Weary, D. M., L. Niel, F. C. Flower, and D. Fraser. 2006. Identifying and preventing pain in animals. Appl. Anim. Behav. Sci. 100:64-76

Whittle, W. L., A. C. Holloway, S. J. Lye, W. Gibb, and J. R. G. Challis. 2000. Prostaglandin production at the onset of ovine parturition is regulated by both estrogen-independent and estrogendependent pathways. Endocrinology 141:3783-3791.

Yeiser, E. E. 2011. The use of activity measures in combination with physiological factors as indicators of disease in dairy cattle. Thesis. Department of Dairy Science, Virginia Tech, Blacksburg.

Yeiser, E. E., K. E. Leslie, M. L. McGilliard, and C. S. Petersson-Wolfe. 2012. The effects of experimentally induced Escherichia coli mastitis and flunixin meglumine administration on activity measures, feed intake, and milk parameters. J. Dairy Sci. 95:4939-4949. 